The Canadian Journal of Higher Education, Vol. XXV-2, 1995

La revue canadienne d'enseignement supérieur, Vol. XXV-2, 1995

\title{
Students' Personal and Academic Attributions of University Withdrawal
}

\section{GENEVIEVE M. JOHNSON* \& GEORGE H. BUCK*}

\section{Abstract}

A Commission of Inquiry on Canadian University Education recently reported that approximately $42 \%$ of full-time undergraduate students who entered Canadian universities in 1985 failed to obtain a degree within five years. While this statistic is startling, perhaps, of greater concern is the apparent lack of interest shown by most Canadian universities in the subject of undergraduate student attrition. As an initial step toward addressing the issue of Canadian university attrition, a conceptual model of undergraduate student withdrawal is proposed.

The model is based on the assumption that students are characterized by a wide range of personal and academic variables. Such characteristics interact or co-exist with institutional variables such as campus integration. This interaction results in the quality of student academic performance and the nature of student psychological condition. Poor quality of student academic performance results in institution-initiated undergraduate withdrawal; a variety of psychological variables (e.g., satisfaction, stress) result in student-initiated undergraduate withdrawal.

The bases of this model were findings obtained from questioning 498 undergraduate students who had withdrawn from a large Western Canadian university. Personal student characteristics, institutional factors and societal variables frequently emerged as students' attributions of university withdrawal.

* University of Alberta. Special thanks to: the Department of Sociology Population Research Laboratory, University of Alberta, for conducting the telephone questionnaire survey; P. J. Miller, Dean of Student Services, University of Alberta, 1984-1994. 
Student academic performance was validated as the causal factor for institutional-based undergraduate withdrawal and student psychological state appeared critically related to student-based undergraduate withdrawal. From these findings, preadmission counseling, academic and personal student support and an increased commitment to accommodating students are recommended.

\section{Résumé}

Récemment, une Commission d'enquête sur l'enseignement supérieur au Canada indiquait que près de $42 \%$ des étudiants sous-gradués, inscrits pour la première fois dans les universités canadiennes en 1985, n'avaient pas complété leurs études à l'intérieur d'une période de cinq ans. Suite à cette information, la plus grande surprise est à l'effet de l'apparent manque d'intérêt de la majorité des universités canadiennes par rapport au sujet de l'attrition au niveau sous-gradué. Dans cette article, un modèle conceptuel de l'attrition par rapport à cette population est proposé comme une contribution pouvant faire avancer cette question dans les universités canadiennes.

Le modèle est basé sur les prémisses que les étudiants ont des caractéristiques personnelles et académiques variées. Ces caractéristiques interagissent ou coexistent avec des facteurs institutionnels, telle l'intégration dans un établissement universitaire. Cette interaction est le résultat de la qualité de la performance académique de l'étudiant et de la nature de ses conditions psychologiques. Une pauvre qualité de la performance académique de l'étudiant es liée à un départ initié par l'institution, tandis qu'une variété de facteurs psychologiques (exemples: satisfaction, stress) sont liés à un départ initié par l'étudiant sous-gradué.

Les bases de ce modèle se dégagent d'une enquête menée auprès de 498 étudiants sous-gradués. qui on quitté une université de l'ouest canadien de grande taille. Les caractéristiques individuelles des étudiants, les facteurs institutionnels et les composantes sociètales émergent fréquemment comme étant le facteur causal du départ (base institutionnelle) et l'état psychologique de l'étudiant et apparu relié au départ (base étudiante). Suite à ces résultats, des services en counseling préalables à l'admission, les supports académique et personnel aux étudiants et une plus grande volonté de répondre aux besoins des étudiants font partie des recommandations. 


\section{Antecedent findings}

A report of a recent Commission of Inquiry on Canadian University Education (Smith, 1991) suggests that, "it would appear that $42 \%$ of full-time [undergraduate] students who entered a university in 1985 failed to get a degree from that university within five years. About half of these are neither failures or transfers to other universities or colleges" (p. 105). ' In the Commission's view, however, "the statistics are less important than the general lack of interest around the subject" (p. 105). Apparently, there is an attitude pervasive in Canada that a university degree is simply not for everyone and that it is only natural to expect some students to discover their lack of interest or lack of suitability for university after a year or two of undergraduate studies. The data indicate that significant attrition occurs among students with passing grades, so the phenomenon is not merely a matter of the departure of academic misfits. Gilbert (citing Noel \& Levitz) suggests that "there is no real mystery about attrition; students re-enroll when they are having an exciting, substantive learning and personal growth experience that they can relate to their future development and success" (in Smith, 1991, p. 106).

Many private American post-secondary educational institutions, dependent on large student tuition and alumni contributions, hold the position that it is easier to maintain existing students (customers) than to solicit new students. ${ }^{2}$ While this administrative approach differs from most state-funded institutions, such an approach enables privately-funded institutions greater control over their enrollment and size of student body (Lively, 1992). American undergraduate student attrition, consequently, has enjoyed considerably more research attention than has undergraduate student attrition in Canadian universities. Given a variety of economic, historical, political and social differences, American university retention literature cannot be generalized to Canadian institutions easily, although certain elements such as particular student variables may be generalized to Canadian undergraduate populations. Several theoretical models of American college and university attrition have been proposed (Allen \& Nelson, 1989; Metzner \& Bean, 1987; Moline, 1987; Terenzini \& Wright, 1987; Tinto, 1987; Van Overwalle, 1989). Without exception, these models do not differentiate between institution and personal withdrawal decisions. Additionally, such models focus on specific aspects of university attrition only and are thus deficient in comprehensive application. Johnson's (1994) recent model of Canadian university undergraduate student withdrawal, however, is comprehensive in scope and clearly distinguishes between student-initiated and institution-initiated university withdrawal. 


\section{A Canadian Model of Undergraduate Student Attrition}

A wide range of student characteristics has been implicated in undergraduate withdrawal. These may be classified under four main categories: Academic factors (De Rome \& Lewin, 1984; Getzlaf, Sedlacek, Kearney, \& Blackwell, 1984; Grosset, 1991; Johnes, 1990; Van Overwalle, 1989); Personal Variables (Boutsen \& Colbry, 1991; Braxton, Brier, \& Hossler, 1988; Ethington, 1990; Fox, 1986; Lang, Dunham, \& Alpert, 1988; Mallette \& Cabrera, 1991; Metzner \& Bean, 1987; Moline, 1987; Nora, 1987; Theophilides, Terenzini, \& Wendell, 1984); Campus Integration (Allen \& Nelson, 1989; Bers \& Smith, 1991; Stage, 1989; Terenzini \& Wright, 1987); and Institutional Variables (Bauer, 1981; Johnes \& Taylor, 1989; Pascarella \& Terenzini, 1983; Stampen \& Cabrera, 1986). These categories and examples of related characteristics are shown graphically in Figure 1.

Figure 1

Categories and Examples of Characteristics Associated with Undergraduate Student Withdrawal
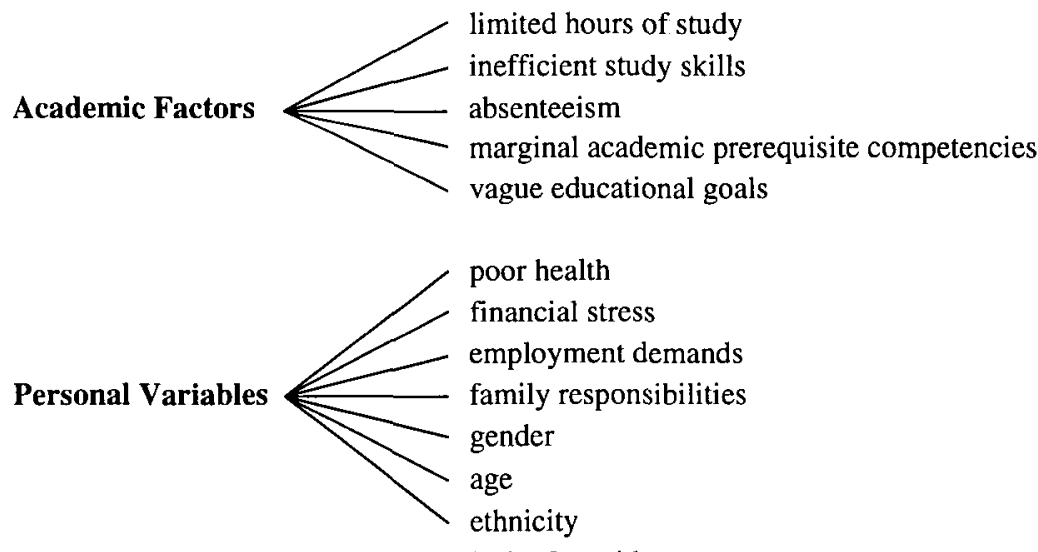
lack of outside encouragement

Campus Integration $\longleftarrow \begin{aligned} & \text { make friends } \\ & \text { join campus clubs } \\ & \text { campus social life }\end{aligned}$ Institutional Variables $\longleftarrow \begin{aligned} & \text { instructor behaviour } \\ & \text { student body size } \\ & \text { support services }\end{aligned}$ 
Students who withdraw are often portrayed as having a particular personality profile or as lacking important attributes prerequisite to university success (Blanchfield, 1971; Munro, 1981). Such stereotypes are reinforced by a discourse of student withdrawal that labels individuals as failures for not having completed their university programs of study (Ott, 1988; Pascarella, Smart, \& Ethington, 1986). In this regard, Tinto (1987) states, "the label dropout is one of the more frequently misused terms in our lexicon of educational descriptors" (p. 3). The term is ubiquitous in describing the actions of all students who leave university without a degree, regardless of the reasons or circumstances that motivated their departure. A distinction must be made between individuals who voluntarily withdraw and those who are required to withdraw by their institution (Hayes, 1977; Simpson, Baker, \& Mellinger, 1980; Tinto, 1987). Figure 2 presents Johnson's (1994) model of Canadian undergraduate student attrition. As can be seen, undergraduate withdrawal is the consequence either of an institutional decision or of a personal decision. The institutional decision is usually based upon inadequate student academic performance, although misconduct such as plagiarism and cheating make necessary some withdrawals.

Personal withdrawal decisions are usually more complex. Students decide to withdraw from their undergraduate programs on the basis of two main factors, summarized in Figure 2 as Academic Performance and Psychological State. Students generate a perception of the quality of their academic performance and evaluate that perception against a personal standard. Each student is characterized by a psychological state that is influenced by, among other things, campus integration and societal forces such as perceived employment options. At the most fundamental level, student academic performance and psychological state are the consequence of an interaction between student academic/personal characteristics and institutional factors. That is, each student is characterized by a unique combination of academic (e.g., study skills, academic prerequisites) and personal (e. g., health, finances, family responsibilities) attributes. This unique combination of student characteristics interacts with institutional variables such as course availability, faculty behaviour and support services. It is the interaction between an individual and an institution that results in student academic performance and psychological state which forms the bases for institutional and personal withdrawal decisions.

\section{Research Questions}

What are the reasons undergraduate students provide to explain their withdrawal from university? To what extent are institution-initiated withdrawals (i.e., students who were required to withdraw) perceived by students to be the 
Figure 2

A Model of Undergraduate Student Attrition

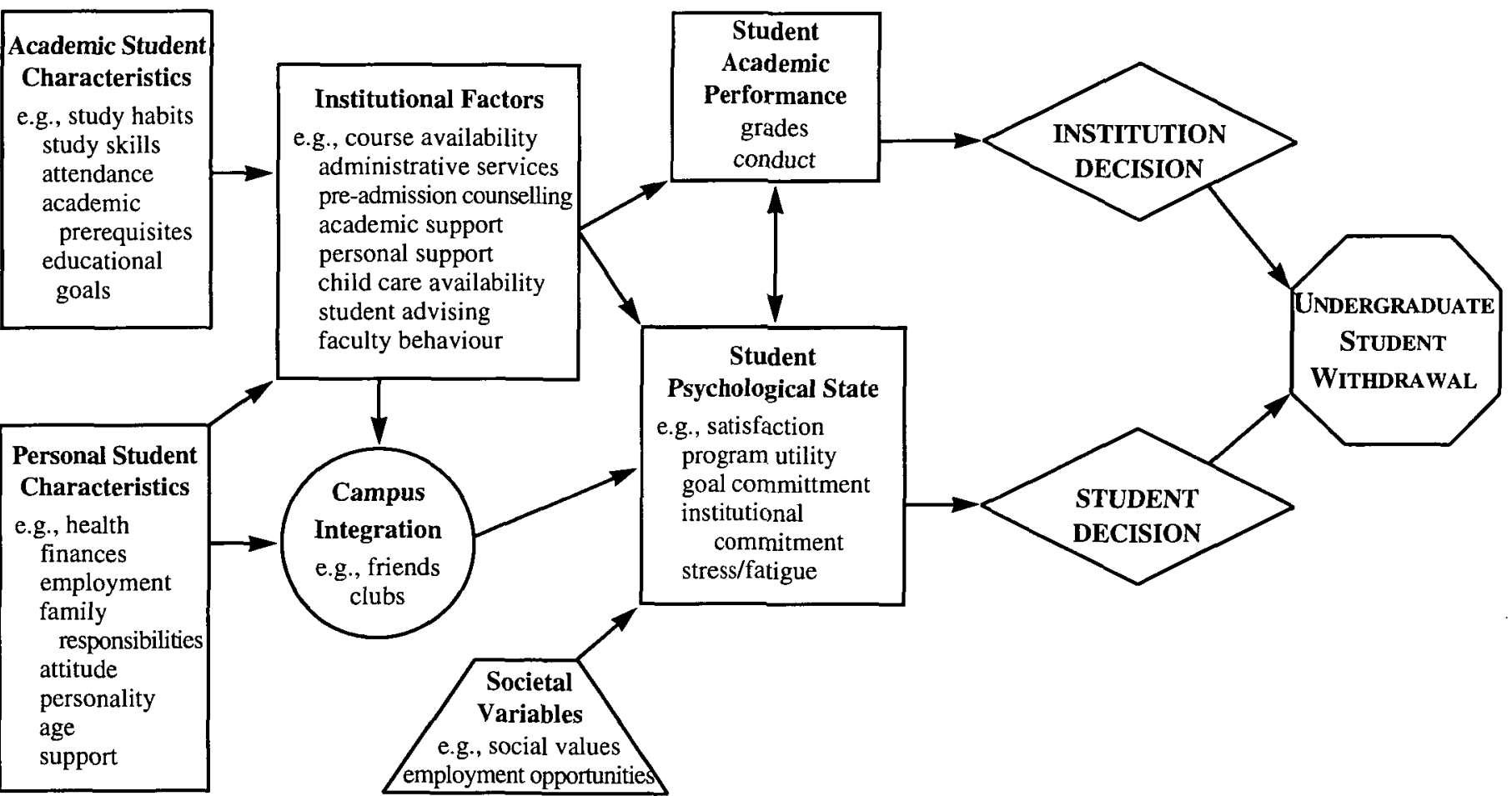


consequence of poor academic performance or of other factors? To what extent are student-initiated withdrawals (i.e., students who voluntarily withdrew) perceived by students to be the consequence of poor academic performance or of other factors? Are there differences in attributions of university withdrawal between students who voluntarily withdrew by completing the necessary withdrawal forms and those who simply did not continue/return as anticipated by the Registrar? How do students interpret the personal consequences of their university withdrawal? Do these interpretations differ for varying withdrawal types? To what extent do university withdrawals actually constitute post-secondary transfers?

\section{Methods and Procedures}

\section{Subjects}

From information obtained from the Office of the Registrar of a large Western Canadian university, it was determined that, during a twelve month period, approximately $10 \%$ of the entire undergraduate population left the university without a degree (excluding students auditing all of their courses, visiting students, special students and unclassified students). This one-year, non-degree departure rate is remarkably similar to those reported recently by the Ontario University Registrars' Association (Gilbert \& MacLean, 1992). That is, from mid September 1991 to mid September 1992, 2,247 undergraduate students left this large Western Canadian university before degree completion. Budgetary restraint made it unlikely that more than $30 \%$ of these withdrawn students could be contacted. Thus, from this group of 2,247 students, the Registrar randomly generated a list of 674 student names and telephone numbers, of which 498 were contacted and agreed to participate in the study. These numbers represent a response rate of $74 \% .^{3}$ For reasons of confidentiality, the Registrar provided no further information regarding these 498 individuals. Thus, at this point, there was no indication of which students had voluntarily withdrawn from university and which had been required to withdraw by the institution. Once contacted, however, students were asked to specify the nature of their university withdrawal. Three distinct groups were identified:

1) Students who were required to withdraw by the institution: 163 of the 498 participants did so at the request of the institution.

2) Students who voluntarily withdrew and completed the appropriate withdrawal forms: 109 of the 498 participants followed official university withdrawal procedures. 
Figure 3

Proportion of sample in each of the three withdrawal groups

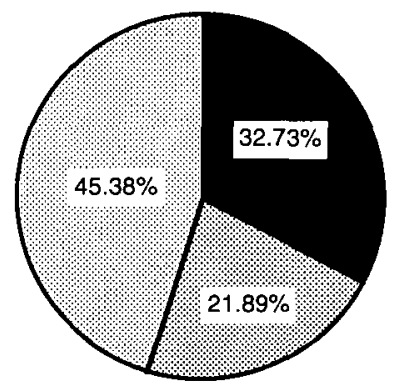

(1) Required to withdraw by the institution

(2) Voluntary withdrawal with appropriate forms

(3) No return with no forms completed

3) Students who did not continue/return and who did not complete the appropriate withdrawal forms: 226 of the 498 participants did not follow official university procedures but rather simply did not continuel return as anticipated by the Registrar.

Figure 3 summarizes the information noted above and illustrates the relative proportions of the three student groups.

The sample of undergraduate students (the 498 participants) who left university without a degree had previously been registered in a total of 17 faculties and programs. Many small faculties, however, contributed only one of their previous students to the sample of subjects. Table 1 represents the number and percentage of each of the students previously enrolled in each undergraduate faculty or program. Table 2 presents the distribution of the sample across year of program. As can be seen, most of the sample withdrew from university during their first year of undergraduate study. Males and females were equally represented in the sample, $49.4 \%$ and $50.6 \%$ respectively.

\section{Data Collection}

In an attempt to maximize subject response rate (e.g., mail out questionnaires were avoided) while minimizing cost (e.g., face-to-face interviews were avoided), a telephone interview questionnaire was developed. The telephone interview questionnaire contained items relating to demographics (e.g., faculty, year of program), reasons for leaving university (e.g., "Why were you required to withdraw from university?') and evaluations of the personal consequences of 
Table 1

Frequency and Percentage of Subjects Previously Registered in each Undergraduate Faculty or Program

\begin{tabular}{|c|c|c|}
\hline \multirow[t]{2}{*}{ Faculty/Program } & \multicolumn{2}{|c|}{ University-Withdrawn Student Group } \\
\hline & Frequency & Percentage of Sample \\
\hline Science & 169 & 33.90 \\
\hline Arts & 103 & 20.70 \\
\hline Education & 87 & 17.50 \\
\hline Engineering & 49 & 9.80 \\
\hline Business & 26 & 5.20 \\
\hline Agriculture and Forestry & 16 & 3.20 \\
\hline Faculté St. Jean a & 14 & 2.80 \\
\hline Nursing & 13 & 2.60 \\
\hline Physical Education and Recreation & 6 & 1.20 \\
\hline Medical Laboratory Sciences & 3 & 0.60 \\
\hline Law & 2 & 0.40 \\
\hline Dentistry & 1 & 0.20 \\
\hline Medicine & 1 & 0.20 \\
\hline Native Studies & 1 & 0.20 \\
\hline Pharmacy & 1 & 0.20 \\
\hline Rehabilitation Medicine & 1 & 0.20 \\
\hline \multicolumn{3}{|c|}{$\begin{array}{l}\text { Faculté St. Jean, consisting of a former independent college, delivers a variety of } \\
\text { programs and courses entirely in French. }\end{array}$} \\
\hline \multicolumn{3}{|c|}{$\begin{array}{l}\text { Table } 2 \\
\text { Freauency and Percentage of Subiects Preyiously Registered in each Year of }\end{array}$} \\
\hline \multicolumn{3}{|c|}{ Frequency and Percentage of Subjects Previously Registered in each Year of } \\
\hline \multicolumn{3}{|c|}{$\underline{\text { Undergraduate Studies }}$} \\
\hline \multirow[t]{2}{*}{ Year of Program } & \multicolumn{2}{|c|}{ University-Withdrawn Student Group } \\
\hline & Frequency & Percentage of Sample \\
\hline First & 201 & 40.4 \\
\hline Second & 151 & 30.3 \\
\hline Third & 88 & 17.7 \\
\hline Fourth & 58 & 11.6 \\
\hline
\end{tabular}


university withdrawal (e.g., "Was leaving university the right decision?"). Questionnaire items were of two types, forced-choice and open-ended. Forcedchoice items must be answered by selecting from a number of fixed alternatives (e.g., yes-no-uncertain). Open-ended items allow respondents to answer in their own words. To preserve the integrity of responses to open-ended items, telephone interviewers were instructed to write down subject's exact response. Following data collection, subject responses to open-ended questions were organized on the basis of common elements.

Subjects were contacted by telephone during February and March 1993. Interviews were conducted on all days of the week, with contact being most frequent on Saturday and Sunday. It was often the case that interviewers had to make repeated attempts to contact students. The average number of callbacks was 3.2 in a range from 0 to 18 .

\section{Data Analysis}

Responses to forced-choice items were compared across the three withdrawal groups, required to withdraw, voluntarily withdrew and did not return, in terms of proportion of the group responding each of the set alternatives (e.g., proportion of the group responding affirmatively). Open-ended item responses were summarized, organized with frequency and then categorized.

\section{Results and Discussion}

Prior to asking, we did not know which students had voluntarily withdrawn, which had been required to withdraw and which had simply not returned to university as anticipated by the Registrar. Having first identified their withdrawal behaviour as one of these three options, students were asked to explain their actions in their own words. Telephone interviewer questioning strategies were standardized to minimize the possibility of response bias. The responses were transcribed exactly by trained telephone interviewers. It should be noted, however, that telephone interviewers did not have sufficient institutional, administrative or educational backgrounds to recognize an inadequate explanation of university withdrawal behaviour. Rather than this being a disadvantage, these limitations of the telephone interviewers permitted participants to respond spontaneously, thus revealing something of their psychological attribution regarding their undergraduate withdrawal. To preserve the integrity of data, that is, to allow students to speak for themselves, responses to open-ended items were collapsed or considered synonymous only when wording was virtually identical. It is for this reason that, in some cases, collapsed student responses may appear almost identical (e.g., disliked courses, disliked university). 
Table 3

"Why Were You Required to Withdraw from University?" - Subjects' First Response

Student Category/Response Frequency Valid Percentage

\section{Program/Administration}

Course concerns

Program problems generally

Transfer/quota problems

University in general

Wrong program

Academic Behaviour/Performance

Marks too low

Academic probation concerns

Failed courses

Examination difficulties

Grade Point Average problems

Poor study habits

\section{Attitude/Personality}

Lack of commitment

University not a priority

Personal/Financial

Death in family

Family reasons

Personal reasons

$\begin{array}{ll}\mathbf{5} & \mathbf{3 . 0} \\ 1 & 0.6 \\ 1 & 0.6 \\ 1 & 0.6 \\ 1 & 0.6 \\ 1 & 0.6\end{array}$

153

93.8

134

82.2

4.3

4.3

1.8

0.6

0.6

1.2

0.6

0.6

1.8

0.6

0.6

0.6

The required to withdraw group, as noted previously, contained 163 students. Table 3 presents a summary of these participants' responses to the question, "Why were you required to withdraw from university?" To facilitate data reporting, responses have been abbreviated and categorized. As can be seen, $93.8 \%$ of participants in the required to withdraw group cited inadequate academic performance as the main reason for their being required to withdraw from university. Specifically, $82.2 \%$ of students in this group stated that their "marks were too low". Several students reported that they had failed courses and a few indicated that they had experienced difficulties with examinations. While academic performance was the most common reason given, several other reasons 
Table 4

"Why Were You Required to Withdraw from University?" - Subjects' Second Response

Student Category/Response $\quad$ Frequency $\quad$ Valid Percentage

Academic Behaviour/Performance

Poor study habits

University workload difficult

Failed courses

Marks too low

Courses difficult

Examination difficulties

Academic probation concerns

Grade Point Average problems

\section{Personal/Financial}

Personal bad health

Family reasons

Too social a lifestyle

Not balanced: work/family/school

Personal reasons

Psychological reasons

Death in family

Financial concerns

Pregnancy

Accommodation difficulties

Divorced/separated

Get practical experience

Student loan problems

Wanted to work for a while

Work at the family business

\section{Attitude/Personality}

Lack of Commitment

Lost interest

Disliked courses

Not sure what to do

University too big

University too impersonal

Have one degree

Needed time off

New career objective

Too competitive
51

24

8

6

5

3

3

1

1

45

8

7

6

5

4

3

2

2

2

1

\section{1}

1

1

1

1

34

13

6

3

3

3

2

1

1

1

1
35.2

16.6

5.5

4.1

3.4

2.1

2.1

0.7

0.7

31.0

5.5

4.8

4.1

3.2

2.6

2.1

1.4

1.4

1.4

0.7

0.7

0.7

0.7

0.7

0.7

23.5

9.0

4.1

2.1

2.1

2.1

1.4

0.7

0.7

0.7

0.7 
Table 4 (continued)

Student Category/Response Frequency Valid Percentage

$\begin{array}{lrr}\text { Program/Administration } & \mathbf{1 5} & \mathbf{1 0 . 3} \\ \text { Wrong program } & 6 & 4.1 \\ \text { Poor teaching methods } & 2 & 1.4 \\ \text { Professors were unavailable } & 2 & 1.4 \\ \text { Too bureaucratic } & 2 & 1.4 \\ \text { Part-time students } & 1 & 0.7 \\ \text { Program problems generally } & 1 & 0.7 \\ \text { Transfer/quota problems } & 1 & 0.7 \\ & & \\ \text { No second response } & 18 & \text { N/A }\end{array}$

were also cited, such as a lack of commitment (Attitude/Personality category) and a death in the family (Personal/Financial category).

After eliciting a first response from participants, telephone interviewers asked a follow-up question, "Was there any other reason that you were required to withdraw from university?" Best interpreted as secondary or underlying student attributions of university withdrawal, Table 4 summarizes these second responses. Only 18 of the 163 participants in the required to withdraw group did not provide a second response. Second responses revealed that participants frequently $(31.0 \%)$ attributed their withdrawal to personal and financial causes (e.g., divorce, death in family, work at family business), often (23.5\%) attributed their withdrawal to reasons of personality and attitude (e.g., lack of commitment, needed time off, university too competitive) and occasionally (10.3\%) attributed their withdrawal to issues related to their programs (wrong program, poor teaching methods, professors unavailable). Thus, it appears, for the most part, that students who were required to withdraw by their institution maintained that the cause of this institutional request was their inadequate academic performance. When queried further, however, a wide range of personal, financial, attitudinal and institutional variables were implicated in institution-initiated university withdrawal.

Table 5 presents a summary of student responses to the question, "Why did you voluntarily withdraw from university?" (asked only of participants who identified themselves as withdrawing by completing the appropriate forms). As can be seen, causal attributions in this group differ greatly from those revealed by students who were required to withdraw. Approximately $50 \%$ of the responses of participants in this group were of a distinctly personal nature 
Table 5

"Why Did You Voluntarily Withdraw from University?" - Subjects' First Response

Student Category/Response Frequency Valid Percentage

Program/Administration
Wrong program
Accepted elsewhere
Prefer practical program
Program lacks career future
Course concerns
Take correspondence
University too big

Academic Behaviour/Performance

Marks too low

Unprepared for university

Courses difficult

Disliked the university

Lack of commitment

Disliked courses

Lost interest

Needed time off

1.8

New career objective

1.8

Not sure what to do

Time to decide the future

\section{Personal/Financial}

50.5

Personal bad health

Family reasons

Financial concerns

Career opportunity

Personal reasons

Psychological reasons

Pregnancy

Moved

Wanted to travel

Needed to make money

Death in family

Divorced/separated 
Table 5 (continued)

"Why Did You Voluntarily Withdraw from University?" - Subjects' First Response

Student Category/Response Frequency $\quad$ Valid Percentage

\begin{tabular}{lll}
\hline Physical/learning disability & 1 & 0.9 \\
Problems because mature student & 1 & 0.9 \\
Student loan problems & 1 & 0.9 \\
Wanted to leave home & 1 & 0.9 \\
Wanted to work for awhile & 1 & 0.9 \\
Work at the family business & 1 & 0.9 \\
Work instead of school & 1 & 0.9 \\
\hline
\end{tabular}

including pregnancy, death in the family, relocation, student loan problems, and financial considerations. Some $18 \%$ of responses were categorized as attitude or personality variables (e.g., lack of commitment, disliked courses). Interestingly, only $4.6 \%$ of the sample of students who voluntarily withdrew reported that they did so because of poor academic performance.

Upon providing a first response, participants in the voluntary withdrawal group were then asked, "Was there any other reason that you voluntarily withdraw from university?" Best interpreted as secondary or underlying student attributions of university withdrawal, Table 6 presents these second responses. Thirty-three of the 109 students who voluntarily withdrew from university by completing the appropriate forms did not provide a second reason for their selfinitiated university withdrawal. These second responses, however, were similar to subjects' first responses. The only notable difference was that second responses were even more likely than first responses to fall in the general category of personal/financial variables. This finding appears to suggest that students who withdraw voluntarily from undergraduate studies do so for a variety of program, attitudinal, personal and financial reasons. Inadequate academic performance comprised approximately $5 \%$ of the cases.

Table 7 presents a summary of student responses to the question, "Why did you not return to university?" (asked only of students who identified themselves as voluntarily withdrawing but not completing the appropriate forms). As can be seen, participants' causal attributions for not returning were similar to those identified in the group previously described (those who withdrew voluntarily by completing the appropriate forms). That is, students did not return to their university undergraduate programs, for the most part, because of personal/financial reasons or for reasons that are best described as personality/attitude variables. 
Table 6

"Why Did You Voluntarily Withdraw from University?" - Subjects' Second Response

\begin{tabular}{|c|c|c|}
\hline Student Category/Response & Frequency & $\underline{\text { Valid Percentage }}$ \\
\hline Program/Administration & 19 & 25.0 \\
\hline Poor teaching methods & 4 & 5.3 \\
\hline Program lacks a career future & 3 & 3.9 \\
\hline Professors unavailable & 3 & 3.9 \\
\hline University too big & 3 & 3.9 \\
\hline Wrong program & 3 & 3.9 \\
\hline Accepted elsewhere & 1 & 1.3 \\
\hline Program not offered & 1 & 1.3 \\
\hline Transfer/quota problems & 1 & 1.3 \\
\hline Academic Behaviour/Performance & 5 & 6.6 \\
\hline Marks too low & 3 & 3.9 \\
\hline Grade Point Average problems & 1 & 1.3 \\
\hline University workload difficult & 1 & 1.3 \\
\hline Attitude/Personality & 4 & 5.3 \\
\hline Have one degree & 2 & 2.6 \\
\hline Lack of commitment & 2 & 2.6 \\
\hline Personal/Financial & 48 & 63.2 \\
\hline Needed time off & 5 & 6.6 \\
\hline Personal bad health & 5 & 6.6 \\
\hline Financial concerns & 4 & 5.3 \\
\hline Moved & 4 & 5.3 \\
\hline Prefer practical program & 4 & 5.3 \\
\hline Lost interest & 3 & 3.9 \\
\hline Not balance work/family/school & 3 & 3.9 \\
\hline Not sure what to do & 3 & 3.9 \\
\hline Disliked university & 2 & 2.6 \\
\hline Needed to make money & 2 & 2.6 \\
\hline Personal reasons & 2 & 2.6 \\
\hline Problems because mature student & 2 & 2.6 \\
\hline Accommodation difficulties & 1 & 1.3 \\
\hline Death in family & 1 & 1.3 \\
\hline Family reasons & 1 & 1.3 \\
\hline Get practical experience & 1 & 1.3 \\
\hline Needed a change & 1 & 1.3 \\
\hline Student loan problems & 1 & 1.3 \\
\hline University too expensive & 1 & 1.3 \\
\hline Wanted to travel & 1 & 1.3 \\
\hline Wanted to work for awhile & 1 & 1.3 \\
\hline No second response & 33 & N/A \\
\hline
\end{tabular}


The two notable differences between the two groups are: a) participants who withdrew voluntarily without completing appropriate forms reported that fewer personal/financial variables had influenced their decision to withdraw than did participants who withdrew by completing the necessary forms; and b) participants who withdrew voluntarily without completing appropriate forms identify slightly more withdrawal attributions of a program/administrative nature $(34.1 \%$ of the cases) than did students who withdrew from university by completing the appropriate forms (26.9\% of the cases). Apparently not completing required forms, at least in some situations, may reflect passive-aggressive hostility to the university.

Following the provision of a first response, a second question was asked by the telephone interviewers; "Was there any other reason that you did not return to university?" Best interpreted as secondary or underlying student attributions of university withdrawal, Table 8 presents students' second response. Of the 226 participants who withdrew without completing the necessary withdrawal forms, 79 did not provide a second causal explanation of their university departure. Concerning the second response, explanations of a program/administrative nature (course not offered, lacks career future, university too bureaucratic) were reported most frequently $(40.1 \%)$. Attitude/personality variables were cited in $23.1 \%$ of the cases. Thus it would appear that undergraduates who withdraw from university by simply not returning do so for a wide range of administrative, attitudinal, personality, personal and financial reasons.

To ascertain student interpretation of the personal consequences of undergraduate withdrawal, the sample of students who withdrew, in all categories, was questioned as to the effect of university withdrawal on their personal and professional lives. Table 9 summarizes these findings. It is important to note that several participants stated that the question was not applicable to them because they felt that the withdrawal decision was made for them by the particulars of their situation. For example, from the category of students who left university without completing the necessary withdrawal forms, a few participants felt that they had not made a withdrawal decision but, rather, had merely reacted to environmental dictates. In the main, however, most participants responded to the question, "Was leaving university the right decision?" with one of the three possible choices; yes, no, uncertain. More than $66 \%$ of students who were required to withdraw reported that withdrawing was an appropriate course of action. For students who withdrew voluntarily by completing the necessary forms, $84.1 \%$ stated that they had made the right decision. Thus it would appear that institution-instigated withdrawal is interpreted negatively by students in approximately $33 \%$ of the cases and student-initiated withdrawal is 
Table 7

"Why Did You Not Return to University?" - Subjects' First Response

Student Category/Response $\quad \underline{\text { Frequency }} \quad$ Valid Percentage

\begin{tabular}{|c|c|c|}
\hline Program/Administration & 77 & 34.1 \\
\hline Take practical program & 11 & 4.9 \\
\hline Wrong program & 11 & 4.9 \\
\hline Accepted elsewhere & 10 & 4.4 \\
\hline Transfer/quota problems & 10 & 4.4 \\
\hline Course not offered & 6 & 2.7 \\
\hline Part-time student & 6 & 2.7 \\
\hline Program lacks career future & 6 & 2.7 \\
\hline Program not offered & 5 & 2.2 \\
\hline Program problems in general & 5 & 2.2 \\
\hline University too big & 3 & 1.3 \\
\hline Take correspondence & 2 & 0.9 \\
\hline Course concerns & 1 & 0.4 \\
\hline Courses filled & 1 & 0.4 \\
\hline Academic Behaviour/Performance & 10 & 4.4 \\
\hline Marks too low & 2 & 0.9 \\
\hline Failed courses & 2 & 0.9 \\
\hline University workload hard & 2 & 0.9 \\
\hline Unprepared for university & 2 & 0.9 \\
\hline Courses difficult & 1 & 0.4 \\
\hline Program too difficult & 1 & 0.4 \\
\hline Attitude/Personality & 43 & 19.0 \\
\hline University not a priority & 10 & 4.4 \\
\hline Disliked courses & 6 & 2.7 \\
\hline Disliked university & 5 & 2.2 \\
\hline Needed time off & 5 & 2.2 \\
\hline Lost interest & 4 & 1.8 \\
\hline Needed time to decide the future & 4 & 1.8 \\
\hline Not sure what to do & 4 & 1.8 \\
\hline Have one degree & 2 & 0.9 \\
\hline Lack of commitment & $\cdot 2$ & 0.9 \\
\hline Went to university too soon & 1 & 0.4 \\
\hline Personal/Financial & 96 & 42.5 \\
\hline Financial concerns & 17 & 7.5 \\
\hline New career objective & 10 & 4.4 \\
\hline Pregnancy & 9 & 4.0 \\
\hline Career opportunity & 8 & 3.5 \\
\hline
\end{tabular}


Table 7 (continued)

"Why Did You Not Return to University?" - Subjects' First Response

\begin{tabular}{lll}
\hline Student Category/Response & Frequency & Valid Percentage \\
\cline { 3 - 3 } & & \\
\hline Moved & 8 & 3.5 \\
Personal bad health & 8 & 3.5 \\
Married & 6 & 2.7 \\
Personal reasons & 6 & 2.7 \\
Family reasons & 4 & 1.8 \\
Need to make money & 4 & 1.8 \\
Wanted to travel & 4 & 1.8 \\
Not balanced work/family/school & 3 & 1.3 \\
Student loan problems & 3 & 1.3 \\
Wanted to leave home & 2 & 0.9 \\
Wanted to work for awhile & 2 & 0.9 \\
Psychological reasons & 1 & 0.4 \\
University too expensive & 1 & 0.4 \\
\hline
\end{tabular}

interpreted negatively by students in about 15 to $20 \%$ of the cases. While these numbers may appear to be relatively small, in a large university such as the one from which the sample was drawn, such proportions translate into hundreds of students each year.

From the information summarized in Table 10, we see that many students who withdrew from university reported that they were continuing post-secondary education elsewhere. Of those continuing, the majority are studying on a full-time basis. Almost half of the required to withdraw group, for example, reported continuing their education, and of that number, $69.3 \%$ stated that they were studying on a full-time basis. In fact, $40.4 \%$ of those students who withdrew voluntarily but did not complete the appropriate withdrawal forms reported continuing their studies; almost one-third reported that they were doing so on a part-time basis. As suggested by the literature, for some students, university withdrawal may be part of a personal path of self-discovery as individuals learn through experience which educational environments are best suited to their personal situations. This observation begs the question, is there a more efficient method of aligning students to educational institutions? 
Table 8

"Why Did You Not Return to University?" - Subjects' Second Response

Student Category/Response Frequency Valid Percentage

Program/Administration

Prefer practical program

Part-time student

University too big

Take correspondence

Courses filled

Professors unavailable

Program not offered

Lacks career future

Accepted elsewhere

Poor teaching methods

Transfer/quota problems

University too bureaucratic

Wrong program

Course not offered

Academic Behaviour/Performance

Marks too low

Courses difficult

Attitude/Personality

Needed time off

Not sure what to do

Needed a change

University too impersonal

Disliked university

School not a priority

Time to decide about the future

Disliked courses

New career objective

Lack of commitment

Lost interest

University too competitive

Personal/Financial

Not balanced school/work/family

Financial concerns

Moved

Psychological reasons

Wanted to work for awhile
59

40.1

13

8

8

7

3

3

3

3

2

2

2

2

2

1

8.8

5.4

5.4

4.8

2.0

2.1

2.0

2.0

1.4

1.4

1.4

1.4

1.4

0.7

6

4.1

3.4

0.7

34

23.1

5

3.4

3.4

2.7

2.8

2.0

2.0

2.0

1.4

1.4

0.7

0.7

0.7

48

32.7

7

4.7

5

3.4

3.4

5

4

2.7

3 
Table 8 (continued)

"Why Did You Not Return to University?" - Subjects' First Response

\begin{tabular}{lcc}
\hline Student Category/Response & Frequency & Valid Percentage \\
\cline { 2 - 3 } & 3 & 2.0 \\
University too expensive & 2 & 1.4 \\
Death in family & 2 & 1.4 \\
Family reasons & 2 & 1.4 \\
Have one degree & 2 & 1.4 \\
Married & 2 & 1.4 \\
Personal bad health & 2 & 1.4 \\
Pregnancy & 2 & 1.4 \\
Wanted to travel & 1 & 0.7 \\
Divorced/separated & 1 & 0.7 \\
Get practical experience & 1 & 0.7 \\
Physical/learning disability & 1 & 0.7 \\
Problem because mature student & 1 & 0.7 \\
Student loan problems & 1 & 0.7 \\
Unable to get part-time work & 1 & 0.7 \\
Wanted to leave home & & NA \\
No second response & 79 & \\
\hline
\end{tabular}

Table 9

University-Withdrawn Student Group Responses to the Question. "Was Leaving University the Right Decision?"

University-Withdrawn Student Group Percentage Responding

Yes Freq. No Freq. Uncertain Freq. NA Freq.

$\begin{array}{lrrrrrrrr}\text { Required to Withdraw } & 67.5 & 110 & 20.5 & 33 & 7.8 & 13 & 4.2 & 7 \\ \text { Voluntarily Withdrew } & 84.1 & 92 & 11.5 & 12 & 4.4 & 5 & 0.0 & 0 \\ \text { Did Not Return } & 80.0 & 181 & 8.3 & 19 & 11.3 & 25 & 0.4 & 1\end{array}$


Table 10

University-Withdrawn Student Group Responses to Questions Concerning Continuation of Postsecondary Education

University-Withdrawn Student Group Percentage Responding

Yes Freq. No Freq. Full-time Freq.Part-timeFreq.

$\begin{array}{lrrrrrrrr}\text { Required to Withdraw } & 45.2 & 74 & 54.8 & 89 & 69.3 & 51 & 30.7 & 23 \\ \text { Voluntarily Withdrew } & 38.9 & 42 & 61.1 & 67 & 75.0 & 31 & 25.0 & 11 \\ \text { Did Not Return } & 40.4 & 91 & 59.6 & 135 & 69.9 & 64 & 30.1 & 27\end{array}$

\section{Conclusions and Implications}

From the findings of this study, several patterns emerge. First, as might be expected, it is first year undergraduate students whose ranks are diminished most significantly by withdrawal, followed, in descending order, by those in subsequent years of the program. Secondly, the findings of Smith (1991), that significant attrition occurs among students with satisfactory grades, coincided with the findings of this study. The finding that factors other than academic performance were often provided as secondary or underlying attribution of university withdrawal strongly suggests that many students may have failed but not necessarily nor exclusively because of a lack of academic ability. If non-academic factors result in less than adequate academic performance, we are forced to wonder if a waste of talent or ability might be remedied by modified institutional practices or policies. That $33 \%$ of students who were required to withdraw claimed that their university withdrawal had not been a correct decision adds credibility to this interpretation.

What is surprising is that, of those students who withdrew voluntarily, the majority $(67.46 \%)$ did so without bothering to complete the appropriate withdrawal forms. This rather abrupt means of departure suggests that many of these individuals neither desired nor anticipated returning to the same university in the foreseeable future. As noted previously, this method of departure may reflect passive animosity directed toward the university because of cumbersome bureaucracy and other administrative factors. This possibility is disturbing, not only because largely non-academic factors instigated these withdrawals, but also because there appear to be few, if any, mechanisms in place to redress such 
factors. Moreover, with the ascendance of the business model of management applied to institutions of higher education, where the student is considered analogous to a customer (Holcomb, 1993), the loss of customers in this way is likely to result in criticism leveled at universities in general. It would serve universities on two planes, therefore, to consider identifying and reducing some of the non-academic institutional factors that contribute to student withdrawal. This process may be facilitated by institutions adopting the model depicted in Figure 2, and on this basis, examine their administrative procedures and solicit their undergraduate populations directly for indications of what non-academic aspects of the institution are considered cumbersome, inadequate, or inappropriate. This process might be accomplished by printing questions in the form of a survey that would appear in the student newspaper.

By involving students in the process of altering administrative procedures, two considerations are addressed. First, potential non-academic factors that could contribute to withdrawal are identified and, therefore, can be remedied. Secondly, the sentiment expressed by several participants in this study (Table 9) that withdrawal was an environmental dictate, would be diminished as students would have opportunity to contribute to the possibility of changing their environment.

Another factor contributing to undergraduate student withdrawal appears to be whether the program selected entails only general studies, or is a course of study leading to professional employment in that particular field. Table 1 shows that the highest percentage of withdrawals occur in the Faculties of Arts and Science, whose degree programs are not especially intended to prepare the student for specific employment. Although these two faculties possess higher undergraduate enrollments than the other faculties listed, it seems that many. students who enroll in general degree programs do so to ascertain where their interests lie. While some individuals might consider this finding to be an indication that more career-based and professional programs should be offered at the expense of programs of general study, in keeping with the so-called business model of administration (Holcomb, 1993), it must not be forgotten that a university is not a trade school. One of the fundamental purposes of a university is to disseminate a wide-range of knowledge and to let the student explore and discover what she or he wishes to investigate in greater depth. If a general arts or science program should lead an individual to conclude that they prefer to pursue an interest and/or career outside of the purview of the university, then the time spent in the general program has not been a waste. 


\section{Notes}

1 These findings are derived from a background report, Attrition in Canadian universities, by Sid Gilbert, University of Guelph.

2 This notion of private retailing is largely foreign to Canadian universities and most American state universities primarily because they have been, in this century at least, supported by public funding.

3 It should be noted that not all of the individuals on the list could be located or contacted.

\section{References}

Allen, D.F., \& Nelson, J.M. (1989). Tinto's model of college withdrawal applied to women in two institutions. Journal of Research and Development in Education, 22, 1-11.

Bauer, W.K. (1981). Strategies for recruiting and retaining the nontraditional student. College Student Journal, 15, 234-238.

Bers, T.H., \& Smith, K.E. (1991). Persistence of community college students: The influence of student intent and academic and social integration. Research in Higher Education, 32, 539-556.

Blanchfield, W.C. (1971). College dropout identification: A case study. Journal of Experimental Education, 40, 1-4.

Boutsen, F.R., \& Colbry, S.L. (1991). Single-parent college students' attributions toward academic success. Psychology in the Schools, 28, 360-364.

Braxton, J.M., Brier, E.M., \& Hossler, D. (1988). The influence of student problems on student withdrawal decisions: An autopsy on the "autopsy" studies. Research in Higher Education, 28, 241-253.

De Rome, E., \& Lewin, T. (1984). Predicting persistence at university from information obtained at intake. Higher Education, 13, 49-66.

Ethington, C.A. (1990). A psychological model of student persistence. Research in Higher Education, 31, 279-293.

Fox, R.N. (1986). Application of a conceptual model of college withdrawal to disadvantaged students. American Educational Research Journal, 23, 415-423.

Getzlaf, S.B., Sedlacek, G.M., Kearney, K.A., \& Blackwell, J.M. (1984). Two types of voluntary undergraduate attrition: Application of Tinto's model. Research in Higher Education, 20, 257-268.

Gilbert, S., \& MacLean, J. (1992, June). Measuring attrition/retention rates in Ontario universities. Paper presented at the Annual Conference of the Association of Registrars of Universities and Colleges of Canada, Moncton, NB.

Grosset, J.M. (1991). Patterns of integration, commitment, and student characteristics and retention among younger and older students. Research in Higher Education, $32,159-178$.

Hayes, S.C. (1977). Dropouts' dissatisfaction with university. The Australian Journal of Education, 21, 141-149.

Holcomb, J.H. (1993). Educational marketing: A business approach to schoolcommunity relations. New York, NY: University Press of America.

Johnes, J. (1990). Determinants of student wastage in higher education. Studies in Higher Education, 15, 87-99. 
Johnes, J., \& Taylor, J. (1989). Undergraduate non-completion rates: Differences between UK universities. Higher Education, 18, 209-225.

Johnson, G.M. (1994). Undergraduate student attrition: A comparison of students who withdraw and students who persist. Alberta Journal of Educational Research, 15, 337-353.

Lang, G., Dunham, R.G., \& Alpert, G.P. (1988). Factors related to the academic success and failure of college football players: A case of mental dropout. Youth and Society, 20, 209-221.

Lively, K. (1992, November 4). Deep cuts in state spending produce a bitter mood at San Diego State. The Chronicle of Higher Education, A21-A23.

Mallette, B.I., \& Cabrera, A.F. (1991). Determinants of withdrawal behavior: An exploratory study. Research in Higher Education, 32, 179-194.

Metzner, B.S., \& Bean, J.P. (1987). The estimation of a conceptual model of nontraditional undergraduate student attrition. Research in Higher Education, 27, 15-38.

Moline, A.E. (1987). Financial aid and student persistence: An application of causal modeling. Research in Higher Education, 26, 130-147.

Munro, B.H. (1981). Dropouts from higher education: Path analysis of a national sample. American Educational Research Journal, 18, 133-141.

Nora, A. (1987). Determinants of retention among Chicano students: A structural model. Research in Higher Education, 26, 31-59.

Ott, M.D., (1988). An analysis of the predictors of early academic dismissal. Research in Higher Education, 28, 34-48.

Pascarella, E.T., Smart, J., \& Ethington, C. (1986). Long-term persistence of two-year college students. Research in Higher Education, 24, 47-71.

Pascarella, E.T., \& Terenzini, P.T. (1983). Predicting voluntary freshmen year persistence/withdrawal behavior in a residential university: A path analytic validation of Tinto's model. Journal of Educational Psychology, 75, 215-226.

Simpson, C., Baker, K., \& Mellinger, G. (1980). Conventional failures and unconventional dropouts: Comparing different types of university withdrawals. Sociology of Education, 53, 203-214.

Smith, S.L. (1991). Commission of inquiry of Canadian university education. Ottawa, Canada: Association of Universities and Colleges of Canada.

Stage, K.F. (1989). Reciprocal effects between academic and social integration of college. Research in Higher Education, 30, 517-530.

Stampen, J.O., \& Cabrera, AF. (1986). Exploring the effects of student aid on attrition. Journal of Financial Aid, 16, 28-39.

Terenzini, P.T., \& Wright, T.M. (1987). Influences on students' academic growth during four years of college. Research in Higher Education, 26, 161-179.

Theophilides, C., Terenzini, PT., \& Wendell, L. (1984). Relation between freshmenyear experience and perceived importance of four-major educational goals. Research in Higher Education, 20, 235-252.

Tinto, V. (1987). Leaving college: Rethinking the causes and cures of student attrition. Chicago, IL; University of Chicago Press.

Van Overwalle, F. (1989). Success and failure of freshman at university: A search for determinants. Higher Education, 18, 287-308. 